\title{
BRITAIN'S SCIENTIFIC SHRINES (6)
}

\author{
By Eng.-CAptain EDGAR C. SMITH, O.B.E., R.N.
}

\section{$\mathrm{A}$} THE NORTH-WESTERN COUNTIES MONG the men of science who passed their lives in the north of England, a special place belongs to the young clergyman Jeremiah Horrocks (1619?-41) and his friend William Crabtree (1610 42 ?), the first of mankind to observe the passage of the planet Venus across the sun's disk. Both were Lancashire men, Horrocks being a native of Toxteth, now within the boundaries of Liverpool, and Crabtree a native of Broughton, near Manchester. The story of their achievement is fully told in Grant's "History of Physical Astronomy". From 1632 until 1635 Horrocks was at Emmanuel College, Cambridge. Home again, he became a tutor, then went as curate to Hoole, eight miles south-west of Preston. Crabtree, on the other hand, was a clothier, but by the age of twenty-six was in correspondence with Horrocks. Their calculations led to the prediction that the transit would occur on Sunday, November 24, 1639, and both prepared to observe it, one at Hoole, the other at Broughton. Favoured by breaks in the clouds at the critical time, both were successful and, as Grant wrote: "Thus did two young men, cultivating astronomy together in a state of almost complete seclusion in one of the northern counties of England, enjoy the privilege of witnessing a phenomenon which human eyes had never before beheld, and which no one was destined again to see until more than a hundred years had passed away". What Horrocks might have achieved had he lived longer no one can say, but his early death, on January 3, 1641, must be regarded as one of the great losses to science in Britain. Crabtree also passed away within a year or two, and owing to the upheaval of the Civil War, the papers and correspondence of both barely escaped destruction. Though in a letter sent to King George III in February 1768, asking for assistance in observing the transit of 1769 , the Royal Society referred to Horrocks, neither then, nor for long afterwards, was anything done to honour Horrocks's memory, and it remained for the Lancashire gardener, weaver and scientific lecturer, Moses Holden (1777-1864), to erect at his own expense in 1826 a memorial to Horrocks in St. Michael's Church, Toxteth. Later on, in 1859, a memorial chapel and window were added to Hoole Church, and in 1879, when the transits of 1874 and 1882 were attracting much attention, a tablet with an inscription by Dean Stanley was placed at the west end of Westminster Abbey. Four years later, one of the frescoes by Ford Madox Brown in Manchester Town Hall was devoted to Crabtree and his observation of the transit.

Other frescoes in the Manchester Town Hall recall the work of the canal builders, Brindley and the Duke of Bridgewater, John Kay of Bury, the inventor of the 'fly shuttle', and Manchester's most famous man of science, the Quaker teacher, chemist and physicist, John Dalton. There was never any likelihood of Dalton's work being forgotten, for after his death on July 27,1844 , wrote Lord Playfair, "Manchester gave him the honours of a king. His body lay in state and his funeral was like that of a monarch". His massive granite tomb is in Ardwick Cemetery and his statue, together with that of his pupil and successor, James Prescott Joule, stands in the entrance to the Town Hall. Dalton hailed from Cumberland, being born on September 6, 1766, at Eaglesfield, near Cockermouth, and near by in the graveyard of Pardshaw Hall is a memorial to him erected a few years ago by the Society of Friends. Nearly a century before Dalton was born, Cumberland was the birthplace of another famous Quaker scientific worker, George Graham (1673-1751), who was born at Horsgills, in the parish of Kirklinton; but he went to London to serve an apprenticeship, and now lies with his master, Thomas Tompion, in Westminster Abbey, whither he was carried on the night of November 24, 1751, his pall being supported "by Dr. Knight, Mr. Watson, Mr. Canton, Mr. Short, fellows of the R.S., Mr. Catlyn, and Mr. Bird, intimate friends of his". In the eighteenth century, when the majority of British natural philosophers devoted themselves to physical inquiries and astronomy, London was a great centre for clock, instrument and telescope makers, among whom none had a higher reputation than Graham and his fellows from the North Country, among whom were John Harrison (1693-1776), of Yorkshire; John Bird (1709-76), a native of Durham; Jesse Ramsden (1735-1800), another Yorkshireman ; Thomas Earnshaw (1749-1829), who was born at Ashton-underLyne, Lancashire ; and Edward Troughton (17531835), like Graham a native of Cumberland. The clocks, chronometers, sextants and telescopes of these great artists were found in ships and observatories all over the world. A bust of Troughton is in the keeping of the Royal Observatory, Greenwich, the tomb of John Harrison in Hampstead churchyard was reconstructed in 1879 by the Worshipful Company of Clockmakers, and in 1931 the Company joined with the British Horological Institute in erecting a tablet to Earnshaw outside the church of St. Giles-in-the-Fields, Bloomsbury, where Earnshaw worshipped and was buried. Of the other men of science of whom Cumberland can boast, Dr. William Browning (1711-1800) practised for many years at Whitehaven, where he made experiments on the gases from mines. In 1766 he was awarded the Copley Medal of the Royal Society for his "Experimental Enquiry into the Mineral Elastic Spirit or Air contained in Spa Water", and a few years later assisted Franklin with his experiments on stilling the waves of Derwentwater by the use of oil. Browning died in retirement at Ormathwaite, near Keswick. From Whitbeck in Cumberland came another original and versatile man of science, the Rev. William Pearson (1767-1847), a promoter of the Royal Institution, a founder of the Astronomical Society, and the owner of an observatory at South Kilworth, Leicestershire, of which he was rector for thirty years and in the church of which he has a memorial.

There are other names which might perhaps be included in this brief review of the worthies of Cumberland; but no excuse is needed for recalling that it was at Stoneraise Place, Wigton, on July 2, 1862, that Sir William Bragg was born. From 1923 he was Fullerian professor at the Royal Institution and director of the Davy Faraday Research Labora- 
tory and during 1935-40 president of the Royal Society. He died on March 12, 1942.

Westmorland no less than Cumberland had her mathematicians and experimentalists, among whom were William Gibson (1720-91), a native of Boulton, near Appleby ; Adam Walker (1731 ?-1821), who was born at Patterdale; and the blind John Gough (1757-1825), of Kendal. All having taught themselves taught others. Gibson, who had a school at Cartmel in Lancashire, was a correspondent with many other mathematicians; Adam Walker became a successful lecturer on scientific subjects in London and at Westminster, Eton, Winchester and other schools; and Gough, at his school at Kendal, counted among his pupils Dalton and Whewell. Though blind from the age of three, Gough made many contributions to the Transactions of the Manchester Literary and Philosophical Society and other periodicals. Among Walker's friends was the painter George Romney, who died in Kendal in 1802, and in the National Portrait Gallery is Romney's picture of Walker, his wife and daughter and three sons, the youngest of whom, Deane Franklin Walker (17781865), continued his father's lectures at the great public schools. The contemporaries of Gibson, Walker and Gough included the Rev. Anthony Shepherd (1721-96), a native of Kendal, who became Plumian professor at Cambridge, master of mechanics to George III and canon of Windsor ; Bishop Richard Watson (1737-1816), who was born at Heversham and is buried and commemorated in Windermere Church; and Thomas Garnett (1766-1802), of Casterton, who was trained as a surgeon by John Dawson (1734-1820), of Sedburgh, and at Edinburgh, and became the first professor of natural philosophy in the Andersonian Institution, Glasgow, and also the first professor of natural philosophy in the Royal Institution. His early death was due to typhus fever. Watson, like Shepherd, was educated at Cambridge, and though, as he himself admitted, he knew nothing of chemistry, was appointed professor of that subject. The post, however, was admirably filled, and Watson afterwards published volumes of chemical essays. To him the Navy owed its first lightning conductor, a chain of copper rods, one end of which, on the approach of a thunderstorm, was triced to the masthead while the other end was allowed to trail in the sea. Like others, Watson was a pluralist-he held several livings and during 1782-87 was Bishop of Llandaff. He died at his estate, Calgarth Park, Westmorland.

The mention of that rather remarkable character, John Dawson, justifies a short detour from Westmorland to Sedburgh and Dent in the north-west of Yorkshire, for Dawson, overcoming his early lack of schooling, not only became a competent surgeon but also a good mathematician, who saw several of his private pupils become senior wranglers. Among this group was Adam Sedgwick (1785-1873), the great geologist, son of the curate of Dent, in the beautiful Dentdale, which was described in a letter by Airy in 1841 and again by A. C. Ramsay in a letter in 1865, who from "Dent, Kendal" wrote : "to old Adam Sedgwick telling him how pleased I am to be in his old home ....". Sedgwick was perhaps the most popular man in Cambridge, and Geikie wrote of his "hard featured yet noble face, eyes like an eagle's, manly alike in body and mind, full of enthusiasm, ready and graphic in talk, generous and sympathetic, shrinking from no toil either at home or abroad in furtherance of his chosen branch of science". He was buried in Trinity College Chapel, and his name is perpetuated by the Sedgwick Museum of Geology, in which is his statue.

Entering Lancashire from Westmorland, just across the border are found Whittington, the birthplace of the shoemaker, gunner, experimenter and lecturer, William Sturgeon (1783-1850), who gave the world its first electromagnet, and Lindale, where can be seen the cast-iron column erected to the famous iron-master John Wilkinson, who lies in a cast-iron coffin not far away. Another column, but of stone and fashioned like a lighthouse, can be seen on Hoad Hill, Ulverston. This was erected in 1850 in memory of Sir John Barrow (1764-1848), who, long the secretary of the Admiralty, promoted Arctic exploration and was the virtual founder in 1830 of the Royal Geographical Society. Barrow's birthplace was a small cottage at Dragley Beck, Ulverston, and in this is a tablet recalling his services and referring to the remarkable vigour of his mind. The cottage was presented to Barrow's son, who gave it to the Ulverston Urban District Council together with the plans of the monument on Hoad Hill. Another spot near Ulverston, Lowick, was the birthplace of Dr. Joshua King (1778-1857), another of Gough's pupils. He became a fellow of Queens' College, Cambridge, and died in the President's Lodge; he was the predecessor of Sir George Stokes in the Lucasian chair of mathematics. Sturgeon's career began with his apprenticeship to a harsh and mean shoemaker, but it took him into the Westmorland Militia, into the Royal Artillery at Woolwich, to the East India Company's College at Addiscombe, to the Adelaide Gallery of Practical Science in London, and in 1840 to the Royal Victoria Gallery at Manchester. Known to Dalton and Joule and a contributor to the Transactions of the Manchester Literary and Philosophical Society, he died as poor as when he was born, and was buried at Prestwich, near Manchester. In 1847, it is recorded, he gave four lectures on electricity and optics at the Green Dragon Inn, Kirkby Lonsdale, Westmorland, two miles from his birthplace, and in Kirkby Lonsdale Church is a marble tablet to his memory.

If a century ago Sedgwick was the most popular man in Cambridge, William Whewell (1794-1866), who was born at Lancaster, was certainly the most masterful. His energy, learning and influence were immense, and he ruled Trinity College like a captain does a battleship. The son of a carpenter, he attended Lancaster Grammar School, and before entering the University of Cambridge read mathematics with John Gough. From his eighteenth year Cambridge was his home. Sir Francis Galton, who belonged to a younger generation, and who graduated from Trinity College in 1844, in his "Momories of my Life", gave an amusing account of the great man courting Lady Affleck, and quoted the lines:

"You may roam where you will through the realms of infinity

And find nothing so great as the Master of Trinity"

which he had from Lord Kelvin; he also said that readers of Whewell's "Life" would gather from it "little idea of the rough power of the man and his too frequent overbearing attitude. In after days," Galton added, "he invited me to the Lodge, where I found him unexpectedly gracious." To-day, a statue of Whewell stands in the ante-chapel of Trinity College beside those of Bacon, Barrow, Newton, 
Macaulay and Tennyson, and in Lancaster Church he has a memorial window. Lancaster was also the birthplace of Whewell's famous friend and contemporary, Sir Richard Owen (1804-92), whose destiny took him first to Edinburgh and then to London. Yet another son of Lancaster was Henry Cort (1740-1800), the Navy Agent who revolutionized the wrought-iron industry and gave the new race of engineers and shipbuilders the bars and plates needed for their rails, boilers, engines, bridges and ships. Misfortune dogged his later years, and like many another benefactor who has died poor, he passed away unhonoured and unsung. His grave in Hampstead churchyard long lay neglected, until in 1905 an American citizen, Charles H. Morgan (1831-1911), of Worcester, Mass., a past president of the American Institute of Mining Engineers, found and renovated the tombstone and provided a bronze tablet for the porch of the church at Hampstead and another for the church at Lancaster.

From Lancaster to Preston is a matter of eighteen miles, and at Preston begins the great manufacturing area associated with the eighteenth century pioneers of the textile industry. Preston itself was the birthplace of Richard Arkwright ; Blackburn and Accrington were the scene of the early labours of James Hargreaves (1720 ?-78). Bury was the home of John Kay (1704-?), and Bolton the birthplace of Samuel Crompton (1753-1827). Hargreaves appears to have no memorial ; but Kay's cottage is still standing and the Bury and District Textile Society is trying to have it preserved. Bolton has long done justice to the memory of Crompton, for his statue stands in one of its squares and his old home, "Hall-i'-th'Wood", a small timbered mansion, has been preserved through the action of another famous son of Bolton, the first Lord Leverhulme (1851-1925). Horrocks's connexion with Hoole, near Preston, has already been mentioned, and Preston now, in Moor Park, has its own Jeremiah Horrocks Observatory. To the north of the town at Woodplumpton is to be seen the memorial to the clergyman's son, Lieutenant Henry Foster (1796-1831), R.N., who accidentally lost his life in the Chargres River. He had entered the Navy at the age of sixteen as a volunteer, and his scientific work during Arctic voyages had gained for him in 1824 the fellowship of the Royal Society and in 1827 the Copley Medal. In 1828, given the command of the Chanticleer, he set out on a long voyage of scientific research from which he never returned.

"At the time of Crompton's birth," said The Times on the occasion of his centenary in 1927, "Lancashire was a wild stretch of country and the towns in it contemptible; at the time of his death it was a hive of prosperity." This prosperity was shown by the great increase in population. It is believed that in 1700 the five most populous counties of England were Middlesex, Somerset, Gloucestershire, Wiltshire and Northamptonshire; in 1800 they were Middlesex, Lancashire, the West Riding of Yorkshire, Staffordshire and Warwickshire. With this increase of population had come the construction of canals, the improvement of roads and the speeding-up of traffic. No place felt the impact of the Industrial Revolution more than Manchester, the population of which increased from 22,000 in 1780 to 160,000 in 1824.

It was the beginning of this period which saw, in 1781, the foundation of the Manchester Literary and Philosophical Society, which became almost a Royal
Society for the north-west. Since the days of Crabtree, until the middle of the eighteenth century, Manchester had produced few if any notable men of science; but with the founding of the Literary and Philosophical Society it became a centre for the scientifically minded, and the story of the Society and of the College founded by the will of John Owens (1790-1846), and of the University to which the College gave birth, would fill many a volume. But all that can be done here is to recall the beginnings of things and some of the men who brought them to pass. As in so many matters, it was the medical men who set the ball rolling, and the two names most closely associated with the founding of the Society are those of Dr. Thomas Percival (1740-1804) and the surgeon-apothecary Thomas Henry (17341816). It was at the house of Percival that the Society was brought into being; it was Percival who was its first president and it was Henry who was its first secretary. Born at Warrington, and a student of the Warrington Academy, where Priestley at one time taught, Percival took his degree of M.D. at Leyden in 1765 and two years later set up in practice in Manchester, becoming known as one of her most public-spirited citizens. He died in Manchester but was buried in Warrington Church. Henry was no less active in the interests of science and the people of Manchester, and when he died he left a son, Dr. William Henry (1774-1836), who, like his contemporary Dalton, added greatly to the fame of the Philosophical Society and gained for himself the coveted Copley Medal. Refined in manner, eloquent in speech, his society was much coveted. "He was 'an accomplished and original man; one who advanced science and took a prominent place among the chemists of the age." It was in 1794 that Dalton became a member of the Society, and for more than forty years it was his scientific home. Within its walls he taught, lectured, wrote and experimented and was its president from the time of the death of Thomas Henry, being elected each year unanimously save for a single vote-his own! Joule, who was born at Salford in 1818 and died at Sale, Cheshire, in 1889, of course, belonged to a later generation, but it was on him Dalton's mantle fell.

From 1799 onwards, the home of the Society was at 36 George Street, and when the Society in 1931 celebrated its one hundred and fiftieth birthday, it was addressed by Sir J. J. Thomson (1856-1940), who was born at Cheetham, Manchester. At that time it was said that No. 36 George Street "has externally an old world appearance, with pillars in front and a porch finely panelled in mahogany. Internally it is most attractive and preserves an atmosphere of studious calm in a district long ago given up to commercial activities. ... Of Dalton relics the Society has an unequalled collection." On the night of December 24, 1940, during an air-raid, the building, its memorial tablet to Percival, its busts and portraits of distinguished men, and its library of 50,000 volumes, were completely destroyed, and from the debris all that was recovered relating to Dalton was his watch, a eudiometer and some charred papers. The same fate also overtook the Cross Street Unitarian Chapel, where both the Henrys were buried.

The temptation is to continue the story of the scientific worthies of south Lancashire, and to review the work of the founders of her great chemical industry, to visit the haunts of some of her famous engineers, to trace the birth and 
development of the scientific institutions of Liverpool and to say something of the interesting Liverpool Observatory and Tidal Institute, which, like the Royal Greenwich Observatory, was founded in the interests of navigation.

Eut perhaps suffecient has been said of the work of the pioneers in a county which, in more recent times, has seen some of the most notable triumphs of the methods of scientific research of which Dalton and Joule were such masters.

\section{WORLD COMMUNICATIONS : THE IMPACT OF SPEED}

$\mathrm{T}$

HE Division for Social and International Relations of Science of the British Association held an open meeting on "World Communications: The Impact of Speed" in the Pollock Hall, University of Edinburgh, on August 13; Sir Harold Hartley was in the chair.

Sir Edward Appleton, principal and vice chancellor of the University of Edinburgh, opened the discussion by sketching briefly the technical advances of radio which permit intelligence to girdle the earth almost instantaneously. He emphasized that these changes have all occurred within approximately the past halfcentury. Marconi's morse signals were the first relatively simple step; but even they were capable of trans-Atlantic transmission by the then unexplained natural bonus provided by the Heaviside layer, which reflects radio waves back to earth and continues to zig-zag them around its circumference. It required, however, the development of the radio valve to make the more complicated speech and music signals amenable to transmission.

The importance of research into the reflecting properties of the ionosphere in the technical advance of international radio communications was emphasized by Sir Edward, and he explained how its variation demands the use of compromise wave-lengths the value of which changes over the twenty-four hours. Ionospheric 'radio weather' is subject, however, only to slow and small change, which, after twenty years research, is predictable.

The competition for the short wave bands which girdle the earth is tremendous, because of their unique value to instantaneous world-wide transmission, and this impact of speed encourages disregard of inter. national agreement of wave-bands, especially for purposes of propaganda.

For broadcasting within fairly narrow national boundaries, the medium wave-lengths are favoured. But here the increase of night.range caused by reflexion creates the international interference nuisance, and for this reason very short, non-interfering, escaping wave-lengths are being favoured for broadcasting speech and vision domestically. They would also relieve the congestion on the longer wave bands. The impact of speed is the demand for more people to use more of it.

Concern is being felt about the amount of radio noise and the need to reduce the unnecessary element in it. The prime need for simple code message, speech or television is to convey it untrammelled. There is enough radio noise inherent in broadcasting. In addition, the wastage of radio channel space on propaganda was deplored by Sir Edward, for large areas must be flooded with strong signals to reach inferior receivers. If the speed of radio communica- tions could be accompanied by world peace and co-operation, greater radio efficiency would result. Verbiage in the air could be cut down to advantage, more especially in English. These points emphasized the urge to economy in radio channel space which these much-sought speedy communications demand.

Sir Edward concluded that the disadvantages faced by radio to-day are largely of man's own making. Science is neutral and will continue to seek truth, and, if the impact of speed is to be for good, it is for ourselves to make it so.

Sir Ben Lockspeiser, secretary of the Department of Scientific and Industrial Research, followed, tracing the impact of speed in aviation. The 10 miles per hour flight of the Wright Brothers heralded a transport revolution because of hitherto unsurmountable barriers being lowered. But the Wright aircraft was all excrescences, and, as these were'shorn away in later types, ever-improving speeds were achieved. Cockpits were built in, struts and bracing wires disappeared, monoplane replaced biplane, undercarriages were retracted, and all manner of gear was built flush in the structure to give the streamlined modern aircraft. But with the streamlining of the aerodynamicist had to come the research of the structural engineer and engine designer to reduce weight as well as drag. With increasing speed comes increasing drag; but an economic margin of pay load and range must be maintained for military cr commercial purposes, and the impact of speed is to induce the collaboration of all scientific workers to reduce structural weight, engine weight per horse power and fuel consumption. Metallurgist, structural engineer and aero-engine makers have combined to reduce weight, and fuel consumption was reduced until the arrival of 100 octane fuel.

Profile drag has been cut to a minimum by wind. tunnel experiment and the mathematical analysis of results by aerodynamicists.

Despite all these gains in speed, a halt to increase would have come in 1945, but for Whittle's jet engine, with its high thrust and propulsive efficiency increasing with speed, enabling the shock waves near the sonic barrier to be overcome. The propellerdriven aircraft was unlikely to have exceeded $\mathbf{5 5 0}$ miles per hour.

New aerodynamic design with swept-back wing, delaying onset of shock waves, combined with the use of thin wings, slim fuselage, swept-back tail and fin surfaces and jet engines have created the new efficiency embodied in the British Comet transport aircraft, the impact of the speed of which will bring London within 18 hours of Johannesburg.

The historical review of world communications over the past half-century having been traced by the first two speakers, Dr. Edward Warner, director of the International Civil Aviation Organization, considered the impact of speed on contemporary world society, and especially the impact of the aeroplane's speed. Here he gave a warning that increased speed is not the only significant characteristic of air transport. Of all the revolutionary changes in world transport, aircraft spell the greatest flexibility and emancipation from routes and permanent way.

Air transport has created quite new social, economic and political conditions. The 'remote places of the earth' have become economically accessible and new culture contacts have sprung up, with inevitable awakening of interest in world affairs for remote peoples. The aeroplane has brought medical services where there were none before. Commercial relations, 